\title{
Édipo Rei: tragédia da memória suprimida por um vate sem visões
}

\author{
Kathrin H. Rosenfield ${ }^{1}$
}

\begin{abstract}
Picking up F. Hölderlin's suggestion, this article proposes a new interpretation of Oedipus' dialogue with Tireisias. In our reading this scene does not stage the protagonist's blindness in face of the oracle, but dramatizes Tireisias' intrigue: the prophet tries do suppress the memory of the past, in order to hide his own disasterous intervention at the time of Oedipus' birth.
\end{abstract}

Key words: Sophocles, Hölderlin, Oedipus Rex, detective story

Resumo: Partindo da leitura de F. Hölderlin, esse artigo propõe uma outra leitura do diálogo entre Édipo e Tirésias. Essa cena não põe em cena a cegueira do protagonista diante dos signos secretos do oráculo, mas dramatiza a intriga de Tirésias que procura suprimir a memória afim de ocultar o fracasso de seu próprio envolvimento na exposição do filho real - isto é, seu fracasso na função de vate.

Palavras chave: Sófocles, Hölderlin, Édipo, história de detetive

\section{$* * *$}

Não seria Édipo Rei uma tragédia voltada inteiramente para o problema da memória? Uma leitura cuidadosa não descobriria uma trama interessantíssima em torno do esquecimento - ora natural, ora deliberado - de fatos relevantes do passado? Não há no centro dos conflitos que envolvem o herói, Creonte e Tirésias todos os traços de táticas de recalque de uma memória de erros, vergonhas e culpas que querem se reapresentar, mas são rechaçados pela cortina de fumaça de oráculos falsamente enigmáticos e de supostas predições sobre o futuro que, na verdade, não passam de hipóteses deduzidos de fatos lembrados, porém cuidadosamente silenciados?

Desde a famosa leitura de Friedrich Hölderlin, há mais de dois séculos, dispomos de uma abordagem que desmistificou a cena inicial - o oráculo anunciado por Creonte

1 Kathrin Holzermayr Rosenfield nasceu na Austria e vive em Porto Alegre desde 1985. Leciona na UFRGS (Filosofia e Letras). Entre as publicações recentes: Antigone: De Sophocle à Hölderlin, Paris, Galilée 2003 (versão Ingles The DAvies Group, Aurora, USA, 2010); Desenveredando Rosa, Rio, Topbooks 2006 (ganhou Prêmio Mario de Andrade da Biblioteca nacional); Édipo Rei: História de uma Intriga Palaciana (em preparação para The Davies Group, 2011). Trabalha atualmente sobre R. Musil e Heinrich v. Kleist (traduções e ensaios críticos). 
contém apenas um pequeno núcleo de profecia délfica (basicamente a mensagem que Tebas está poluída e precisa ser purificada antes que seja tarde), consistindo essencialmente de deduções, hipóteses e associações que os dois protagonistas projetam sobre a verdade muito genérica anunciada pela Pitonisa. Perseguindo essa sugestão, pode $\operatorname{mostrar}^{2}$ que o diálogo de Édipo e Creonte no Prólogo traz à tona poucas verdades divinas, porém muitos elementos de uma intriga humana: esforços por parte de Creonte de esquecer as vergonhosas falhas de um passado sombrio: primeiro, o escândalo de um passado mais recente (o assassinato de Laio), episódio no qual a esposa e o cunhado negligenciaram o enterro de um rei e a purificação de sua morte violenta; segundo, esses detalhes apontam para vergonhas e temores mais antigos: Creonte, Jocasta e Tirésias relutam em lembrar-se da audácia que os levou a suprimir o herdeiro recém-nascido do trono, afim de garantir a vida e o poder de Laio e de seus aliados (Jocasta e Creonte que governam com ele). Por essa via, descobre-se uma segunda trama que constitui uma verdadeira intriga palaciana contra a memória: Jocasta, Creonte e Tirésias, felizes com a salvação da cidade por Édipo, tentam esquecer Laio, para deixar morrer com ele as terríveis lembranças daquele reino: suprimir o próprio filho, embora seja uma prática legalmente permitida, sempre acarreta temor do retorno do espírito dessa criatura morta. Suprimindo a lembrança desse temor decorrente de um ato vergonhoso, os governantes de Tebas suprimem, ao mesmo tempo, a memória das noções éticas fundamentais da cidade. Todo o percurso do herói, nesse sentido, consiste na reconstituição da trama de lembranças, noções e valores que assegura a ordem hierárquica dos membros da família e do estado.

Eis a perspectiva que levará também a uma outra leitura da cena com o vate. Enveredaremos por um caminho diferente das interpretações predominantes, que entendem essa cena como uma dramatização da cegueira do protagonista diante dos signos secretos do oráculo. Desviando a atenção da suposta miopia do herói, mostraremos como Tirésias procura ocultar o fracasso de seu próprio envolvimento na exposição do filho real, isto é, seu fracasso na função de vate.

\section{Os segredos e enigmas - mui profanos - de um vate}

Sófocles é famoso por sua ironia mordaz e profunda. A fama do 'supreme ironist' deveria nos inspirar alguma dúvida quanto à imagem convencional deste poeta, visto geralmente como um conservador religioso e pacato. Ela poderia ser a projeção dos leitores, que lêem sua tragédia como se ela pudesse ser compreendida a partir de concepções arcaicas da vidência e dos oráculos - ideias que seriam pouco conciliáveis com o iluminismo grego $^{3}$. É muito mais provável que Sófocles tenha compartilhado o ceticismo dos líderes atenienses com respeito às interpretações supersticiosas e demagógicas dos oráculos e tenha visto o papel problemático, embora importante, de instituições como Delphos ${ }^{4}$. Édipo Rei desenvolve do modo mais insistente certa dubiedade das práticas proféticas em geral e acentua, ainda mais que em Antígone, as feições profanas de Tirésias. $\mathrm{O}$ vate aparece antes como conselheiro fracassado e amargurado, do que como detentor de profecias. O poeta

2 Kathrin H. Rosenfield, "Dos erros de Sófocles aos indícios concretos do "caso' Édipo", in Phaos. Revista de Estoudos Clásicos, no. 5, Campinas, 2005, PP. 86-93

3 Cf. a observação de F. Ahl à respeito da ousadia social e política do poeta, Two Faces of Oedipus, Cornell University Press, 2008, pp. 7-9.

4 F. Ahl, ibid., p. 98, fala do ressentimento contra instituições como Delphos na decorrência das guerras do Peloponeso, ressentimento esse, que vibra também na obra de Sófocles. 
lhe tira seu halo sagrado e intensifica os traços ambíguos e duvidosos do vate desprezado, cuja carreira e função contém alguns enigmas - começando por sua atitude ambivalente, logo ao entrar em cena.

Tirésias diz enfaticamente que não quer falar. Mas sua relutância não se explica pelo temor de contrariar o herói, nem pelo medo de represálias por parte do tirano. Uma série de comentaristas, entre os quais $\mathrm{F}$. Ahl ${ }^{5}$, salientaram a atitude competitiva do tirano e do vate, que rivalizam pelo saber em busca da verdade. Com efeito, a altivez inicial do herói ao convocar o vate, mais como testemunha do que como profeta, como veremos adiante, inverte-se quando o discurso baralhado de Tirésias toca no segredo da filiação. Nesse momento, Édipo revela seu lado desamparado e fragilizado, implora ao profeta que lhe conte mais, mas este lhe despeja tão somente um rol de verdades tão enigmáticas, que nem sequer os anciãos o compreendem, embora conheçam os fatos do passado. $\mathrm{O}$ que foi pouco comentado, entretanto, é o fato de que a carga agressiva, competitiva e sorrateira parece estar mais na atitude do vate, não tanto na do herói.

Além destas perspectivas, há mais aspectos que chamam a atenção. Em primeiro lugar, Tirésias procura, pelo menos no início, evitar qualquer competição ou rivalidade com o seu governante. Muito pelo contrário, nota-se até o esforço de entrar em acordo, para que Édipo interrompa sua investigação. Porém, não convém ver aí um gesto magnânimo favorecendo ou protegendo a felicidade do herói. Apesar da dramaticidade solene, as fórmulas iniciais logo começam a ter o tom de uma proposta lacônica de cumplicidade esquiva, a atmosfera de um pacto que cimenta poderes e prerrogativas ameaçadas. Com certo enfado, Tirésias parece tentar o impossível - fazer Édipo parar, a fim de evitar os constrangimentos inúteis que surgem quando investigações remontam ao passado longínquo. Veremos que há reiteradas propostas de entendimento implícito, antes de a atitude intransigente do herói provocar uma mudança de tom. Tirésias adota um estilo lacônico e seus sarcasmos começam a soar como deboche contínuo - como a diabólica alegria de um burlador nato que, agora, despista o rei. As ironias impiedosas conferem um ar mais profano à aura do vate, ao passo que os esforços do herói ganham uma aura mais compenetrada, sincera e piedosa ${ }^{6}$.

Fica evidente, sobretudo, que, seja por vontade própria, seja pela atitude de Jocasta que o marginaliza, Tirésias já não exercia mais sua autoridade há tempos. Além disso, também no momento presente do drama não oferece os conselhos ou as diretrizes dos seus vaticínios. Ao que parece, o vate deixou de ser atuante em Tebas devido a algum acontecimento no passado que não fora esclarecido para o novo rei. Embora Creonte tenha aconselhado a convocação do vate antigo, Jocasta mostrará claramente o desprezo que guarda pelos profetas de Apolo. E o leitor deve se perguntar, exatamente como faz o herói, por que o vate não resolvera o enigma da Esfinge, nem revelara a identidade do herói, nem impedira o casamento incestuoso que denunciará mais tarde. Tampouco protesta, como o fez em Antígona, contra a vergonhosa poluição do solo e, principalmente, dos altares, com o sangue dos insepultos. Quais são, ou poderiam ser as razões para tamanha negligência

5 Cf. F. Ahl, Sophocles' Oedipus, Evidence and Self Conviction, pp. 98-102 sublinhando a reversão dos papéis e atitudes; a altivez de Édipo acaba em desamparo, enquanto Tirésias 'triunfa' (101) finalmente sobre o herói que, talvez, 'relegara o vate a um segundo lugar ao solver o enigma da Esfinge' (102).

6 Hölderlin vê Tirésias como o "guardião das potências da natureza" - mas a ideia da "palavra sagrada" tem mais pertinência em Antígona, onde Tirésias procura restabelecer o equilíbrio perdido da ordem dos vivos e dos mortos (que é abalado quando os pássaros começam a dilacerar o cadáver de Polinice, sujando com sangue os altares). O que é notável em Édipo Rei, é o fato que Tirésias não intervem nessa sua função enquanto 'guardião da natureza'!. 


\section{Conexão Letras}

das suas funções? Por que o vate demora a atender o chamado ${ }^{7}$ do rei? Por que ele o atende apesar de não estar disposto a elucidar os enigmas? Por que ele se expõe pela presença física quando tudo mostra que ele retém o que sabe e como soube?

Antes de analisarmos em detalhe a dinâmica deste diálogo, proponho a hipótese de que pode haver mais realismo contemporâneo nesta cena do que normalmente se pensa. Mostrarei que Tirésias não é mais representado como o detentor mítico de verdades divinas, mas como um dos diversos agentes que contribuem para um debate racional, com suas experiências, intuições e reflexões. Um vate da época clássica é visto como uma figura dúbia, que pode ter ao mesmo tempo acesso à verdade "divina" e perseguir estratégias favorecendo alvos meramente humanos.

Os não-ditos criam zonas de sombra que aumentam o suspense e convidam o leitor a observar melhor em que ponto de fuga convergem, e terminam por fazer sentido, as aparentes incongruências. Sófocles confere também ao seu vate o dom poético-irônico de "brincar" com a linguagem: explora e burla as sutis diferenças entre entender, saber e esquecer. Em vez de revelar verdades, o adivinho encena contradições, confunde seu interlocutor com enigmas e lança formulações cujo alvo é o de não serem compreendidas. Por mais que o vate fale, suas palavras expressam, tão somente, a vontade de calar, esquecer e enterrar os fatos do passado, que Édipo procura investigar (316, I 320) :

Como é terrível entender (phroneîn, pensar, saber) onde isto não oferece saída a quem entendeu/reconheceu. Isto, eu o sabia e/mas eu o esqueci [ao vir aqui].

O estranho "silêncio de Tirésias" e o duvidoso alcance dos poderes proféticos do vate de Tebas têm que ser vistos como um artifício especificamente sofocliano, não como uma construção defeituosa, tal como Segal os apresenta:

Os poderes proféticos de Tirésias também levantam algumas questões. Se ele possui
todo este saber antecipado, por que ele não interveio para impedir o casamento de
Édipo e de Jocasta? Por que ele não soube responder ele mesmo aos enigmas da
Esfinge e por que ele esperou tantos anos para declarar que Édipo matou Laio? O
próprio Édipo levanta estas questões (vv. 390-98, 558-68) e elas nunca são explici-
tamente respondidas.

A postura do vate é realmente muito estranha. Mas a estranheza se dissipa quando desistimos da ideia pitoresca do vidente cujas iluminações abririam um canal com os deuses. Sófocles desmantela as crendices e faz de Tirésias um homem cuja experiência superior se deve ao longo tempo que viveu. Quando ele diz, por exemplo, que as revelações viriam do dia/tempo que se encarregará de "conceber e destruir" o herói (438, I 444), ele não profetiza uma verdade que somente um vidente pode saber. Ele sabe, porque acompanhou, no tempo vivido, experiências que escapam ao herói, porque este fora pequeno demais para registrálas. Tirésias não profere oráculos, mas usa uma retórica mistificadora que permite silenciar fatos, que são comprometedores para ele próprio, conhecidos e esquecidos por todos.

Os conselhos de Tirésias, seu convite para interromper a investigação preenchem, consequentemente, um papel específico. Tirésias não procura favorecer o herói, mas assegurar um já frágil e relativo conforto mútuo, isto é, poupar a si mesmo e a Jocasta

7 Knox, loc. cit., p. 74 assinala que o termo grego significa que Tirésias foi "intimado"

8 Ibid., p. 57.

9 Ibid., p. 56. 
e Creonte a revelação do fracassado estratagema da exposição e, ao herói, a denúncia do seu parricídio e incesto. Numa história de detetive, esse tipo de pacto chama-se singelamente de 'cumplicidade'.

As palavras obscuras visam a uma troca recíproca de silêncios, para que continuem esquecidos os conselhos que Tirésias forneceu a Laio e que levaram Jocasta a suprimir o filho maldito e Creonte a concordar com esse gesto cruel. Tirésias diz, com sarcasmo amargo, que fora considerado "sábio" pelos pais do herói e F. Ahl realça bem o estatuto ambíguo do vate, cujo saber está suspenso entre a experiência racional e a adivinhação genial ou 'divina', ao traduzir da seguinte maneira:

E.: Não esperava que irias soltar tantas idiotices. Se soubesse,

Não teria me apressado de convidar-te à minha casa.

T.: Somos como nascemos. Idiotas, tu pensas.

Teus pais, porém, que te geraram, me achavam sensato (433-436, I 438-42).

Com o uso do termo neutro "sensato" encontra-se diminuída a aura sagrada das opiniões do vate. Assim, a altercação do rei e do vate em torno da validade das declarações do adivinho encaixa-se perfeitamente no que sabemos da atitude cética com relação a uma prática tradicional que já evidenciou abusos e perversões. O próprio Tirésias sabe que suas 'verdades' são relativas e que já fora estimado sábio e sensato por Laio e Jocasta, embora o tempo tenha desmentido as esperanças daquele casal e a propriedade dos conselhos do vate. No mundo real e racional, as verdades da vidência começam a ser sujeitas ao tempo e à experiência. Eis a razão pela qual os contemporâneos de Sófocles, por exemplo, Temístocles, começam a recuperá-las com a ousadia ou, até mesmo, o cinismo, que cabe à Realpolitik.

Numa época em que os melhores líderes sabem que profetas, e até instituições como Delfos, são suscetíveis de corrupção e charlatanismo, o herói tem razões subjetivas e objetivas para suspeitar de um complô: ele, mais que ninguém, tem o direito de pensar que o vate usa indevidamente sua arte, fazendo da vidência um ardil e não uma razoável interpretação de oráculos ${ }^{10}$. É perfeitamente justificada a indignação de ter sido ludibriado "com enigmas obscuros" (439, I 445), que inviabilizam o seu esforço de esclarecer o crime de Laio e suas causas, o que inviabiliza também a purificação da cidade. O herói tem razão de se indignar com os enigmas de Tirésias e também acerta quando suspeita que o vate esteja escondendo fatos, atos e intenções relevantes para o bem-estar da polis e do seu soberano. Pois o vate está, realmente, ocultando a trama dos próximos de Laio, que levou à exposição do legítimo sucessor ao trono. A ameaça que o herói sente, no momento presente, já fora real no passado.

Não há, portanto, apenas desmedida tirânica na desconfiança do herói, mas seu faro certeiro intui corretamente as más intenções e violências que o vate desencadeara contra ele no passado ${ }^{11}$. Sófocles construiu essa cena como uma charada, disseminando, na situação presente, em frases e palavras anódinas, alusões a atrocidades nada anódinas do passado.

É curioso ver quão longe vai a dessacralização da figura de Tirésias nessa tragédia. Seus gestos perseguem interesses próprios, suas reticências têm motivos profanos e pessoais. Não há nenhum motivo nobre na sua decisão de calar seu reconhecimento de Édipo. Estamos, simplesmente, diante da manipulação de conhecimentos e testemunhos

10 “Ô riqueza, poder, arte superando a arte na vida repleta de rivalidades!" (H 384-5, Bl 376). Édipo denuncia a arte de Tirésias como "ardil" que falsifica a verdadeira arte da vidência.

11 Cf., entre outros autores, Ch. Segal, loc. cit., pp. 54 e 84 s.. 


\section{Conexão Letras}

que são de praxe nos momentos pouco gloriosos da administração do poder. Nada sobra dos dotes proféticos que o Prometeu de Ésquilo herdou das divindades das origens ${ }^{12}$ e que o Tirésias de Antígona ainda possuía ${ }^{13}$.

A frase inicial "Como é terrível saber/entender...", suscita, de imediato a pergunta: O que Tirésias sabia? É obvio, e a própria tragédia o revela, que Tirésias já sabia, antes do início da ação representada, quem era Édipo. O texto, no entanto, não diz explicitamente quando e como o vate soube. Seria desde a chegada de Édipo em Tebas? Desde o retorno do único sobrevivente? Ou desde o flagelo da peste? Nada indica, muito pelo contrário, que ele tenha descoberto a identidade do herói graças a uma inspiração divina, ou através da algum ritual profético. Como Édipo, ele parece se basear mais em seu sentido de observação. Ele mesmo explicita, aliás, o fato de que seu conhecimento surgiu de fenômenos terrenos, não de signos celestiais. Quando Édipo indaga, com ironia, quem teria fornecido a verdade do miasma que Tirésias agora lhe atribui, o vate responde:

[Eu soube] de ti. Tu me fizeste falar contra vontade [ou:] "Tu me fizeste ler contra vontade os signos $\left(358, \mathrm{I} 361^{14}\right)$.

Tirésias refere-se, evidentemente, aos signos do nome Oidipous que explicita o que aconteceu com os pés do herói. A palavra légein significa tanto falar como ler, decodificar, montar a charada. Portanto, ele ouviu, viu e leu a experiência presente à luz do passado. Foi com desagrado e contra a sua vontade que Tirésias recebeu de Édipo ("de ti") as provas da sobrevivência do filho amaldiçoado de Laio, provas essas que desmentem a sabedoria e a utilidade do vidente de Tebas.

Podemos pensar, como faz F. Ahl ${ }^{15}$, que Édipo, talvez, não tenha tornozelos propriamente mutilados e inchados, mas que sofra tão somente de um estigma simbólico, como a vergonha da história ou do nome aviltante que lhe foram atribuídos, Mas, existem indícios empíricos estabelecendo a relação entre o nome, os pés e a pessoa e esses indícios permitem ao Coríntio provar a veracidade do que diz. Nem Tirésias, nem o Coríntio são totalmente

12 O Titã de Ésquilo dispôs ainda de um saber cósmico e de uma esperança divina que Sófocles reduz a dimensões bem mais terrenas. Prometeu se salva da ira de Zeus porque detém a previsão de que Zeus o seria destronado pelo filho se não renunciasse a sua paixão por Tétis.

13 Cf. Francisco Marshall, loc. cit., p. 154 e B. Knox, em The Heroic Temper, 1966, p. 49, assinalam a correspondência entre o Prometeu acorrentado de Ésquilo e Édipo Tirano. Knox, em The Heroic Temper, 1966, p. 49. Embora o sofrimento aproxime o grande trickster da condição humana, sua obstinação apóia-se num segredo oracular que lhe permite saber de antemão (isto é, antes dos malefícios ocorrerem) o futuro de Zeus. Sua orgulhosa obstinação contra Zeus terá um desfecho feliz, porque seu saber secreto permite antecipar e evitar as nefastas conseqüências do desejo e esta manipulação sobre-humana do segredo lhe garante a liberação num futuro longínquo. Todo este contexto sobre-humano que Ésquilo montará para o seu Prometeu acorrentado é totalmente alterado em Sófocles.

14 Comentaremos, adiante, a relação semântica entre légein e synékho, reunir-se em um ponto, compreender ao juntar o quebra-cabeça; cf. BL 360.

15 Cf. Ahl, Two Faces..., 2008, p. 82, assinala que a ideia dos tornozelos perfurados, mutilados e mal cicatrizados deve-se as versões de Eurípides (As Fenícias, vv. 22 ss.) e Pausanias. Ahl (cf. 2008, pp. 66-68) defende a hipótese de que o "velho mal" (v. 1027) do herói não seria uma mutilação, nem cicatriz físicas, porém a vergonha de carregar um nome ridículo (Pé Inchado) baseado tão somente numa "penosa velha história", emnépeis (v. 1027). Mas Édipo nada soube da sua origem antes do encontro com o Coríntio, o que enfraquece o argumento de Ahl. Pois tanto Jocasta fala de pés atados (v. 817-9) e o Coríntio retoma a mesma imagem quando se refere aos tornozelos como "testemunhando" o mesmo fato (1026). O coríntio insiste que ele, então salvador do bebê, 'liberara' o herói, 'quando teus pés estavam atados ou trespassados' (1029) e que Édipo deve seu nome e o que ele é a esta contingência ou má sorte (tychê) (1030). 
arbitrários quando identificam o salvador de Tebas com o filho estigmatizado de Laio ${ }^{16}$. É esse tipo de decodificação empírica que o herói exigiu do vate logo na saudação inicial (3001 s., I 305-6): sua investigação queria se apoiar precisamente nesses tipos de conhecimento da experiência humana: saberes relacionados com o que se pensa -- livres associações e suposições --, o que se diz -- os rumores -- e o que não se diz -- os indícios indiretos. As intuições divinas são apenas um item entre os outros saberes profanos e terrenos:

Ô Tirésias que tudo pensas/nomeias ${ }^{17}$, o que é dito,

o não-dito/inominável também, o celestial e aquilo que ocorre na terra (I 304-5, 300-1).

Apenas uma das quatro modalidades solicitadas refere-se ao saber propriamente profético, à leitura de signos divinos, observados no vôo dos pássaros. Édipo insiste muito mais na tarefa de "nomear", como se exortasse o vate de falar daquilo que se dizia na época do crime ${ }^{18}$. Em seguida, ele menciona o “inominável” ou "não dito". Dependendo da tradução, esses termos podem referir-se os segredos inomináveis dos deuses, ou, graças à palavra ambígua (arreta, 302, I 306) pode falar também dos segredos que a vergonha, a culpa e a decência humanas tornam tabus e inomináveis. Como último item, Édipo acrescenta ainda a sabedoria que deduzimos da experiência terrena (chthonostibé), de forma que vemos Tirésias convocado mais como cidadão lúcido e observador do que como profeta.

A fala de Tirésias indica que ele reconheceu Édipo, desde sua chegada a Tebas. Havia as marcas dos pés, capazes de suscitar as primeiras suspeitas. Mas havia também a estranha fuga do velho servidor de Laio, que confessou não suportar permanecer sob o olhar do novo soberano. E havia, sobretudo, os dúbios favores da Rainha, que dispensara a única testemunha do assassinato antes de qualquer conclusão ponderada sobre a morte de Laio. Ela jamais perguntara como o servo pôde escapar vivo de um assalto de vários homens, ela não punira a falta de proteger o amo e deixara sem investigação regular um crime que deveria ser a questão principal do Estado. A delicada e incômoda cumplicidade da Rainha com o escravo, outrora encarregado da matança do recém nascido, explica a superficialidade da investigação que relega a morte de Laio a vagos rumores e preenche o desejo de esquecer um passado doloroso e vergonhoso.

16 A tese de Ahl radicaliza demasiadamente a idéia da 'fabricação do pai' de Pietro Pucci. Assim perde-se o foco central do ensaio de Pucci (a coincidência de tyché e telos, acaso e necessidade) e, além de perdermos uma história acabada, teríamos que aceitar o Édipo (fabricado e não-idêntico com a criança exposta) como uma história meta-irônica no melhor estilo vanguardista, que lembra as pegadinhas voluntariosas dos vanguardistas ou as peças pregadas ao leitor por autores como Machado de Assis, Borges e Bioy Casares. Sófocles se permitiria brincadeiras irônicas com o mito, os oráculos e os videntes que provariam uma irreverência um tanto mais que esclarecida. É difícil imaginar Sófocles com um espírito anti-burguês do séculos XIX e XX. Não há na época clássica a malícia anti-filisteia e o pessimismo sociocrítico ou subversivo que se propaga a partir do século XIX e que está fundamentalmente ligada à relação tensa do artista com a sociedade burguesa. É mais provável um olhar irônico e crítico quanto à credibilidade dos intérpretes de oráculos do que uma subversão tão radical. Esta exigiria por parte do público um desapego total com relação aos relatos míticos. Ou então, a ironia de Sófocles permaneceria tão secreta que apenas o crítico irreverente dos tempos modernos consegue decodificá-la.

17 Dos quatro saberes - didakta, arreta, ourania te, kai chthonostibé - as etimologias de três remetem ao nomeado, não-nomeado, e à experiência empírica. Na tradução de F. Ahl (77) "Teiresias, observing everything / that can be taught and all things that defy / expression, what is in the skies above / or walks upon the earth!..."..

18 Creonte e também o Coro mencionam os rumores que circulavam no passado. "O resto são palavras velhas e obtusas", dizem os anciãos (H294), mas eles se recusam a detalhar o que exatamente se dizia. Ao que parece, tudo o que se viu ou ouviu do crime contra Laio suscita por parte do Coro certa repugnância e esquecimento e, por parte dos habitantes do palácio, reticências, ceticismo e lacunas de memória. 
Neste contexto, não é inócuo o trocadilho implícito da palavra "rumor", o termo grego, phátis, que oscila entre o sentido forte de oráculo e o sentido fraco das coisas faladas pela boca do povo ${ }^{19}$. Observa-se, portanto, uma tendência nítida de confundir as coisas mais sagradas, os oráculos, com as mais profanas, como fofocas, chacotas e rumores. Algum impedimento obscuro vedava, mesmo após a liberação da Esfinge, a apuração do assassinato. A corte de Tebas não estava disposta a defrontar-se com a verificação das causas da morte de Laio, como se uma apuração pudesse confirmar suspeitas obscuras ou reavivar más lembranças de um reino maldito. Sófocles deixa entrever que Laio preferiu o oráculo de Delfos aos vaticínios de Tirésias. E a omissão do vate no episódio da Esfinge mostra um mal-estar nas relações dos governantes com o vidente - um incômodo que se deve provavelmente às ameaças e maldições, supostamente burladas, do passado. Os detalhes não explicitados geram um magma de suspeitas vagas, que devem ter agitado as mentes dos cidadãos de Tebas e as dos espectadores e críticos de Édipo Rei.

\section{O silêncio dos tebanos e os fatos "esquecidos" do passado}

Em todo caso, a nebulosa de silêncios e esquecimentos quanto aos fatos sugere que todos sabem muito mais do que dizem, apagando, na própria consciência e nas dificuldades que criapara a investigação do herói, os rastros do passado. Como os habitantes do palácio, também Tirésias faz parte da constelação de angústias, violências e culpas, verdadeiro pântano e fonte inesgotável de fantasmas paranóicos e defensivos. Mesmo assim, ele tem a frieza da velhice, que vê as coisas como são, e não falta um toque de cinismo no apoio que dá ao desejo geral de esquecer o passado. Sua exclamação "Como é assombroso entender quando o entendimento não rende nenhum ganho ao que entende.” (316 s.) é uma sentença universal e um lamento pessoal!

Com efeito, as visões e os conselhos do vate que "parecia sábio" aos olhos de Laio e Jocasta, foram inúteis e, talvez, tenham produzido inquietudes já durante o reino de Laio. Numa das versões míticas, que reaparecerá em Eurípedes, a protetora de casamentos, Hera gamestolos, envia a Esfinge, ainda durante a vida de Laio, como castigo por uma transgressão no âmbito matrimonial. Nessa versão, Tirésias desaconselha a viagem a Delfos e recomenda um sacrifício propiciatório a Hera. Laio, entretanto, descarta o conselho e prefere consultar o oráculo de Delfos, indo, assim, ao encontro fatal na encruzilhada ${ }^{20}$. $\mathrm{O}$ mito, embora seja recente, provavelmente contemporâneo da época clássica, e suscetível de importantes variações, mostra uma ambivalência funcional de Tirésias.

Sófocles intensifica a dimensão profana e a falta de eficácia do vidente: o Coro descarta liminarmente suas acusações contra Édipo e Jocasta tem apenas palavras de desprezo por vaticínios e vates. E quem examina com lucidez suas formulações obscuras, descobre, na verdade, máximas desabusadas da sua inglória e longa trajetória pelas mazelas tebanas.

19 Charles Segal, La musique du Sphinx, Paris, Éditions la découverte, p. 109, assinalou que este termo que designa rumor, palavra espalhada pela boca do povo, significa também "profecia" (nos versos 151, 310, 323, 1440, cf. 495). Comentando o uso do termo por Jocasta, Segal conclui que a rainha, "mesmo combatendo a verdade do oráculo, afirma assim sua estranha verdade. Os rumores públicos são, ao mesmo tempo uma só e mesma coisa com o oráculo privado da casa de Laio.”. Cf. também, Charles Segal, Oedipus Tyrannus. loc. cit...

Num outro contexto, Martin Heidegger, Sein und Zeit, Tübingen, Niemeyer, 1984, retoma a questão do vínculo ontológico que liga a aparência dos rumores com a essência verídica das falas (cf. \# 37, pp. 165-170 'Das Gerede', chacotas e rumores).

20 Essa versão do mito aparece numa escholie das Fenícias (v. 1760) e remete a Peisandros (século VI). Cf. Pauly Wissowa (verbete Laio); 
Tirésias proclama a sabedoria que todos poderiam ter adquirido se tivessem a coragem de olhar em frente e de ouvir o que está sendo dito. Mas, ironicamente, os anciãos de Tebas preferem descartar as informações corriqueiras do ouvir-falar e censuram, na própria memória, os males do passado. Um pouco antes da entrada em cena de Tirésias, o Coro saudou com muita esperança a iniciativa de Édipo que enviara um mensageiro para chamar o vidente. Parece apostar tudo nas revelações do vate e, mais do que isto, parece desconsiderar explicitamente os sinais que sustentam o conhecimento humano. Édipo apostava precisamente nesses pequenos signos empíricos, desconsiderados no passado, e que um interrogatório dos anciãos, de Creonte e de outras testemunhas poderia reconstituir.

Eis uma das razões pelas quais Tirésias trata o herói com certa condescendência, pois o tipo de informação que o rei solicita não é bem da ordem dos vaticínios. Édipo insiste nas lembranças e nos conhecimentos gerais do homem experiente. Tirésias, no entanto, sabe que a investigação não trará nenhum remédio imediato para Tebas. Apenas iluminará, de modo ainda mais cruel, as atrocidades que remontam para além do assassinato de Laio e se prolongam até o presente. Eis a razão mais provável pela qual ele despreza a investida do herói.

\section{O tyrannos e o vate: adversários no domínio do esquecimento e da lembrança}

Tornou-se um lugar comum da crítica ver Édipo como um rival presunçoso que pretende superar Tirésias na arte da vidência. Chama a atenção, entretanto, que Tirésias não reivindica, em nenhum momento, capacidades de revelação profética. Ele até sublinha o relativismo, quando diz que "parecia ser sábio ou ter insights racionais" aos olhos de Laio e Jocasta. De resto, afirma apenas saber-avaliar (phroneîn) - capacidade essa, que caracteriza o cidadão responsável e o tyrannos-benfeitor -, e insinua certas afinidades que o igualam a Édipo. Ele salienta, por exemplo, que ambos carregam fardos semelhantes e que não conviria falar dos sofrimentos obscuros que ambos compartilham. Vejamos as quatro respostas com as quais o vate propõe um silêncio proveitoso para ambos e resiste às exortações de Édipo:

T: Deixe-me retornar à casa. Será mais fácil tu carregares ${ }^{21} \mathrm{o}$ teu / como também eu o meu, se tu seguires [meu conselho] (320-1, I 324-5).

Para além do oráculo, a formulação paralela - carregar o teu / o meu - faz surgir a idéia de um elo íntimo, porém oculto, que vincula as ações e papéis do rei e do vate. Quando Édipo insiste em que ele proclame um oráculo ou revele outras falas esclarecedoras, isto é, hipóteses, induções ou rumores (phátis, no verso I 327), Tirésias o adverte da imprudência de falar demais, o que evoca, em primeiro lugar, o fatal juramento que condenará Édipo ao exílio:

T: O que vejo é que tua própria fala não te favorece, / e que preciso cuidar para que não me ocorra o mesmo (324-5, I 328-9).

Mas além da advertência irônica, que diz respeito aos perigos de Édipo, Tirésias fala em nome próprio: "preciso cuidar para que não me ocorra o mesmo". Em outras palavras, o vate cala porque corre perigo de incriminar-se e condenar-se a si mesmo. Qual é o pensamento por trás desta afirmação? Ela faz sentido somente se lembrarmos que o juramento estabeleceu uma íntima analogia entre o velho e o novo soberano e que Édipo ameaçou

21 Cabe perguntar: carregas o quê? "Teu fardo"?, "a tua coisa”, como sugerem Jean Bollack e Trajano Vieira...? 


\section{Conexão Letras}

de morte e exílio todos aqueles que colaboraram ou foram coniventes com um complô visando à usurpação do trono. Se o vate revelasse a identidade do herói conquistador, ele teria que revelar também que seus vaticínios levaram Laio e Jocasta à ousadia de suprimir o legítimo herdeiro do trono, frustrando a alegria da cidade, que se crê "salva" com a má notícia de que todos os esforços foram vãos. O vate está numa posição particularmente delicada, desde o retorno do herói, pois a vítima sobrevivente transformou-se em salvador amado pelo povo de Tebas. Liberados da Esfinge, os mesmos aliados de Laio somente desejavam esquecer a era sombria do antigo reino. Eis a razão pela qual Tirésias mostra escárnio quando o coro o suplica que revele a verdade. A frase impaciente "Ninguém aqui pensa direito!" denuncia a pouca inteligência dos anciãos, incapazes de ver e entender os elos intrincados entre os fatos:

T: Ninguém de vocês entende-e-pensa direito (phroneit'). Eu, porém, jamais / farei ouvir o meu, nem tampouco o teu mal (kaká) (I 332-3; 328-9).

Tirésias dirige-se, no plural, aos anciãos de Tebas e, talvez, até mesmo a Édipo, acusando-os de não saber pensar "reto" e incitando-os para que silenciem os seus males, a exemplo dele próprio, Tirésias, que mantém velados os seus. De fato, há realmente uma notável inconsequência no pensamento dos anciãos, que têm ao seu alcance os elementos da verdade que nenhum oráculo desvendará. Mas eles preferem silenciar e esquecer, para nunca mais pensar nas crueldades entre parentes. Mesmo assim, as variações da expressão "expulsar de um próximo parente" - ekbalein philos - percorrem, como um refrão, toda a tragédia: ora elas evocam o exílio ou a morte de Creonte, ora lembram a exposição do filho recém-nascido de Laio.

Devido a esse encaixe de culpas antigas e de males recentes, Tirésias responde friamente, quando Édipo o censura de trair a cidade pelo silêncio:

T: Não quero te torturar nem a ti nem a mim mesmo. Por que perguntas em vão? (332-3, I 336-7)

Todas as respostas do vate indicam que ele não se considera externo à ação, numa posição que lhe permitiria dizer qualquer verdade divina. Pelo contrário, ele se declara, ele mesmo, parte e objeto das revelações que o tempo humano trará. Insinua um constante paralelismo entre o seu próprio destino e o do herói. A principal diferença está no fato de que o vate posterga a revelação que Édipo procura apressar. Na sua atitude predomina a frieza, uma falta de afeto e gratidão que é diametralmente oposta à compaixão e à solicitude do herói. Tirésias vê o que é, mas ele não vê nem age como instância religiosa da verdade. Ele penetra os enigmas confusos da experiência com a frieza cruel de certas pessoas muito velhas, cuja lucidez tende a despojar o olhar de toda ilusão e o mundo do seu halo idealizado. Diferentemente dos outros personagens, que rechaçam da própria consciência os elementos que poderiam perturbar a felicidade ilusória e os ideais presentes, a inteligência assustadoramente sóbria de Tirésias livrou-se da esperança, da ilusão e do afeto que conferem às pessoas uma aura amável e às coisas seu véu de beleza. Sófocles transformou de modo realista o motivo mítico da idade exorbitante de Tirésias. $\mathrm{O}$ vate, cuja vida se estende da fundação até a destruição de Tebas, agora traz à tona a essência do cidadão experiente e prudente, que sabe pesar, inclusive melhor que os anciãos, os poréns e os senãos das situações insolúveis. Vendo a impossibilidade de chegar a uma solução satisfatória, ele prefere, como os outros personagens, calar os 
males do passado, pois o destino de Tebas, no final da peça, permanecerá indeterminado e ameaçador. E quem lê Antígona e Édipo em Colono sabe que a descoberta e o exílio do herói não salvarão a cidade dos seus miasmas.

O silêncio de Tirésias, porém, é diferente do dos demais personagens, pois Tirésias se cala sobre o que observou, lembra e sabe. E ele sabe que pode preservar a frágil felicidade de Tebas, tão somente, ao postergar a descoberta e ao favorecer a fuga dos fatos do passado. As metáforas da fuga aparecem desde o diálogo com Creonte. O oráculo teria revelado que somente o "não observado foge" (ekphygein, 111); mas quando Édipo pergunta por testemunhas, Creonte alega que a única testemunha "fugiu" (phygôn, 118). Creonte, Jocasta e o Coro fogem e deixam fugir os fatos, porque insistem em esquecer. Mas a distração do esquecimento permite que o esquecido se insinue novamente nas suas falas. Tirésias, ao contrário, sabe e lembra do que cala. Eis a diferença que torna ambígua e ferozmente irônica sua réplica, quando Édipo o acusa de fugir do interrogatório com uma tática de acusações:

Estou salvo (pepheuga significa também: fugi) [mesmo]. Nutro o verdadeiro (thaletés) com força eficaz (356, I 361).

"Nutrir o verdadeiro" não significa aqui "dizer o que é", senão Tirésias não esconderia em enigmas indecifráveis, que nem o herói, nem o Coro compreendem, as relações incestuosas do herói e da rainha. A ironia gira em torno do duplo sentido de thaletes - termo que significa "o verdadeiro", mas cuja etimologia diz "o não-esquecido". Tirésias "nutre o não-esquecido" e reconheceu Édipo, lembrando da mutilação que Laio infligiu ao seu filho, signo que é sublinhado pelo nome "pé inchado" de Oidipous. Como ele, também o servo de Laio não esquecera a marca dos pés e ligou as coincidências do presente com as lembranças do passado -- predições do oráculo, mutilação dos pés do bebê, pés inchados e idade do assassino que reaparece como salvador de Tebas.

$\mathrm{O}$ retorno triunfal do benfeitor ${ }^{22}$ destruiu a autoridade do vate. $\mathrm{O}$ salvador evidencia que oráculos, embora possam ser verdadeiros, enredam aqueles que os interpretam, exatamente nas suas próprias decisões e escolhas. Tirésias sabe, portanto, que já perdeu de Édipo e que sua experiência apenas lhe permite ganhar mais algum tempo. E ele sabe também que o herói tem a força juvenil de lutar pela verdade, mesmo que esta o atinja e destrua. Tirésias, ao contrário, carrega o peso da velhice, enredada em complexidades e comprometimentos contraditórios. Tudo aquilo que o tempo normalmente torna obsoleto e destrói, como, por exemplo, o reino de Laio e Jocasta e a fidelidade que ele exige, arrasta-se, em Tebas, para a geração seguinte, revelando uma contradição insustentável, um avanço que é retrocesso.

\section{Conclusão: a memória desumana de Tirésias}

Daí a lassidão quase cínica do vate, que não é mais honrados com signos divinos - talvez porque não honrou a memória da cidade. Tirésias vê claro e lembra tudo porque não compartilha nem as angústias, nem as esperanças que movem Jocasta, Creonte e o coro. Estes desejam viver, alegraram-se e iludiram-se com a presença de Édipo ao ponto

22 Cf. Marie Delcourt, Oedipe ou La légende du conquérant, Paris, Les Belles Lettres, 1981, p. 35 e todo o capítulo sobre o pharmakós e o imaginário das ordálias (pp. 29 - 43). A sobrevida comprova no imaginário mítico o potencial benéfico e salvador da criança exposta 


\section{Conexão Letras}

de "esquecer" a relação entre o nome e as marcas dos pés. Tirésias, o ancião que viu tudo porque já serviu várias gerações de monarcas, reúne em silêncio os indícios de mais uma desastrosa involução da cidade.

Faz parte do enigma de Tirésias um certo endurecimento, uma indiferença quase cruel com a perda da memória que causa a desordem na cidade. Seria essa dureza uma forma de cinismo? Ou tratar-se-ia de uma atitude que dá a justa medida da situação cruel e insolúvel na qual o vate vê afundar os habitantes de Tebas?

Mais impressionante do que o contraste entre o saber sagrado e o profano é o contraste entre a tentativa de reconstruir a memória de fatos, nomes, lugares e acontecimentos. Esse esforço aparece na sinceridade afetiva de Édipo que se insurge contra o frio "esquecimento" voluntarioso do vate. O herói expressa sincera indignação quando pergunta se Tirésias seria "pior que os piores, [tão mal] que até [criaturas] feitas de pedra se indignariam” (I 339 s., 334 s.). A exortação convida o vate para que saia da sua indiferença fria, pois a pedra é o termo de comparação mais vil na escala de valores gregos. Mas Tirésias somente devolve o insulto com o intuito de confundir o raciocínio do herói e para impedir que esse encontre, no caos das lembranças ocultadas e dos testemunhos truncados, o fio vermelho da ordem das coisas. Tirésias, além de não ser privilegiado com visões, faz tudo para impedir Édipo de penetrar na memória (deliberadamente) esquecida da cidade. Debocha e se alegra com o fato que "o famoso decifrador de enigmas, não tenha captado a verdade embora essa tenha sido proferida de modo tão claro" ${ }^{23}$. A perda da memória não aflige somente o herói, também o coro falha em compreender os fragmentos truncados do passado vivido e de sua relação com o nome Oidipus - pés mutilados por Laio, pés inchados e marcados por cicatrizes que ainda afligem o rei de Tebas no presente. Tendo lançado os presentes em raciocínios desencontrados, Tirésias profere o pseudo-vaticínio (I 452-460, 447-62), que é formulado para permanecer incompreensível, embora explicite tudo que ele lembra, sabe e deduz de observações passadas e presentes. Seu escárnio se refere ao esquecimento covarde de todos, pois o Coro, Jocasta e Creonte poderiam saber o que ele sabe, se tivessem interrogado o servo de Laio ou conferido os indícios que estavam diante dos olhos com as lembranças do passado.

\section{Referências}

AHL, Frederick. Two Faces of Oedipus. Ithaca: Cornell University Press, 2008.

. Sophocles'Oedipus, Evidence and Self Conviction. Ithaca: Cornell UP, 1991.

DELCOURT, Marie. Oedipe ou La légende du conquérant. Paris: Les Belles Lettres, 1981.

HÖLDERLIN, Friedrich. Oedipus der Tyrann,in: Sämtliche Werke, Frankfurter Hölderlin Ausgabe, (D. E. Sattler, ed.), vol. 16, Stroemfeld/Roter Stern, 1988.

KNOX, Bernard. Oedipus at Thebes, New Haven: Yale University Press, 1957. (Norton, N.Y., 1971)

. The Heroic Temper. Berkeley: California UP, 1966.

MARSHALL, Francisco. Édipo Tirano. A tragédia do saber. Brasília: Editoras UNBUFRGS, 2000.

23 Tal como comenta Ch. Segal, loc. cit., p. 82. O crítico pondera que Édipo estaria distraído com a pressão das suas responsabilidades políticas ou que, talvez, o protagonista poderia estar deixando a cena quando o vate profere as sombrias revelações. No entanto, mesmo neste caso, resta a explicar a incompreensão do coro. Esta se deve ao truque retórico (semear confusão, medo e perplexidade) usado por Tirésias. 
ROSENFIELD, Kathrin H.. Dos erros de Sófocles aos indícios concretos do 'caso' Édipo, In: Phaos. Revista de Estoudos Clásicos, no. 5, Campinas, 2005.

SEGAL, Charles. La musique du sphinx. Paris: La Découverte, 1987.

SÓFOCLES. Édipo Rei. (trad. Trajano Viera). São Paulo: Perspectiva, 2001.

WISSOWA, Pauly. Lexicon der Antike in fünf Bänden Munique: DTV, 1979. 